\section{Effect of Reduced Irrigation on Growth and Flowering of Coneflower and Sneezeweed}

\author{
Amanda Bayer ${ }^{1}$
}

Additional index words. Echinacea, Helenium, sensor irrigation, water stress

SUMMARY. Reduced irrigation (RI) can be used to reduce irrigation volume as well as to control plant growth. The timing and duration of $\mathrm{RI}$ applications can affect overall plant growth and flowering. Knowledge of plant response to RI can allow growers to control growth and plant form. The objective of this study was to quantify flower and overall plant growth of 'PAS702917'coneflower (Echinacea purpurea) and 'Helbro' sneezeweed (Helenium bybrida) in response to RI. A soilmoisture sensor automated irrigation system was used to apply four irrigation treatments: RI and well-watered (WW) controls (25\% or $38 \%)$ and two alternating treatments to apply RI for either the first 2 weeks ( $25 \%$ followed by $38 \%$, RIWW treatment) or final 4 weeks (38\% followed by $25 \%$, WWRI treatment) of the 6 -week study. For the sneezeweed experiment, RI was reduced to $20 \%$. For coneflower, peduncle length was greater for the WW $(36.8 \mathrm{~cm})$ and RIWW treatments $(35.7 \mathrm{~cm})$ than the RI $(27.0 \mathrm{~cm})$ and WWRI treatments $(26.6 \mathrm{~cm})$. Shoot dry weight, compactness, leaf area, and flower number were not significant. For sneezeweed, WW plants were taller $(57.2 \mathrm{~cm})$ and had greater shoot dry weight $(49.8 \mathrm{~g})$ than plants in other treatments. WW plants also had more flowers (99) than WWRI (63) and RI (67) plants, which were more compact. Total leaf area did not differ between treatments for either species. Total irrigation volume was greatest for WW plants (5.2 and $15.1 \mathrm{~L} /$ plant for coneflower and sneezeweed, respectively), with RI at any point during the experiment resulting in water savings.

$\mathrm{R}$ educing irrigation applications in container production is necessary for growers to adapt to decreasing water supplies, reduce the environmental impact of production, and comply with a growing number of regulations regarding nursery and greenhouse water use, fertilizer applications, and nutrient levels in runoff (Chappell et al., 2013; Fulcher et al., 2016). However, growers often prefer to overapply rather than

Received for publication 23 Sept. 2019. Accepted for publication 5 Dec. 2019

Published online 15 April 2020.

${ }^{1}$ Stockbridge School of Agriculture, University of Massachusetts, 210 Bowditch Hall, Amherst, MA 01003

This material is based on work supported by the National Institute of Food and Agriculture (NIFA), U.S. Department of Agriculture (USDA), the Center for Agriculture, Food and the Environment and the Stockbridge School of Agriculture at University of Massachusetts-Amherst, under project no. MAS00487.

I thank Eliza Forrest for her help with this research. I also thank Lindsey Hoffman and Michelle DaCosta for their suggestions on the manuscript.

The contents are solely the responsibility of the authors and do not necessarily represent the official views of the USDA or NIFA.

A.B. is the corresponding author. E-mail: abayer10@ umass.edu.

This is an open access article distributed under the CC BY-NC-ND license (https://creativecommons.org/ licenses/by-nc-nd/4.0/).

https://doi.org/10.21273/HORTTECH04510-19 underapply irrigation and fertilizer out of concern that lower amounts could negatively affect growth (Million et al., 2007; Owen et al., 2008). Improved knowledge of plant water requirements and more efficient irrigation systems allow plants to be produced with not only RI but also reduced labor, fertilizer, pesticides, growth regulators, and production-related energy inputs (Lichtenberg et al., 2013 ). There is also a growing preference of consumers for plants produced more sustainably (Behe et al., 2013).

Consumers expect good-quality, uniform, healthy plant material at a reasonable cost (Brand and Leonard, 2001; Guo et al., 2018). Visual appearance is an important consumer quality for ornamental container plants (Brand and Leonard, 2001). Consumers often purchase plants based on the perception that plant health and visual appearance correspond. Uniform growth, leaves on lower branches, dense foliage, leaf color, and bloom quality can all affect the visual appearance and appeal of a plant to consumers (Brand and Leonard, 2001; Glasgow et al., 1998). In a survey of consumers in New England states, the top characteristic they looked for in a retail establishment was "healthy, fresh, and well-maintained plants" (Brand and Leonard, 2001).

Plant quality control can be a large component of container plant production as uneven growth and poor branching may lead to customer rejection of plant material or poor sales (Koniarski and Matysiak, 2013). Lack of uniformity of plant material can result from uneven irrigation distribution, variation in pruning from person to person, or plant growth regulator application variability by species, substrate, and application timing. Hand pruning is also labor intensive, and plant growth regulators will potentially be restricted due to concerns over chemical use in production, necessitating alternative means of growth control (Kaufmann et al., 2000). Reduced irrigation applications can be used as a method of plant growth control and to improve crop quality (Koniarski and Matysiak, 2013); however, this requires knowledge of species-specific water requirements and uniform irrigation applications. Too little water can result in reduced leaf size, short internodes, reductions in flower size, fewer flowers, and an overall reduction in plant quality (Sánchez-Blanco et al., 2002). Conversely, undesirable plant growth, including excessive growth, long internodes, and large

\begin{tabular}{llll}
\hline $\begin{array}{l}\text { Units } \\
\begin{array}{l}\text { To convert U.S. to SI, } \\
\text { multiply by }\end{array}\end{array}$ & U.S. unit & SI unit & $\begin{array}{l}\text { To convert SI to U.S., } \\
\text { multiply by }\end{array}$ \\
\hline 29.5735 & $\mathrm{fl} \mathrm{oz}$ & $\mathrm{mL}$ & 0.0338 \\
0.0929 & $\mathrm{ft}^{2}$ & $\mathrm{~m}^{2}$ & 10.7639 \\
3.7854 & gal & $\mathrm{L}$ & 0.2642 \\
2.54 & inch(es) & $\mathrm{cm}$ & 0.3937 \\
6.4516 & inch $^{2}$ & $\mathrm{~cm}^{2}$ & 0.1550 \\
28.3495 & $\mathrm{oz}$ & $\mathrm{g}$ & 0.0353 \\
93.0102 & $\mathrm{oz} / \mathrm{ft}$ & $\mathrm{g} \cdot \mathrm{m}^{-1}$ & 0.0108 \\
7.4892 & $\mathrm{oz} / \mathrm{gal}$ & $\mathrm{g} \cdot \mathrm{L}^{-1}$ & 0.1335 \\
0.9464 & $\mathrm{qt}$ & $\mathrm{L}$ & 1.0567 \\
4.9289 & teaspoon $(\mathrm{s})$ & $\mathrm{cm}^{3}$ & 0.2029 \\
$\left({ }^{\circ} \mathrm{F}-32\right) \div 1.8$ & ${ }^{\circ} \mathrm{F}$ & ${ }^{\circ} \mathrm{C}$ & $\left({ }^{\circ} \mathrm{C} \times 1.8\right)+32$
\end{tabular}


variation in leaf size, can result from overapplication of water and fertilizer (Koniarski and Matysiak, 2013). Plants with uneven growth are less likely to sell in a retail setting and may require additional labor and resources to improve salability. Water stress during shipping and while in a retail setting can also result in unsalable plants due to reduced visual appeal (Hall et al., 2011). Another benefit of deficit irrigation is the potential to help plants gain tolerance to drought stress conditions that may be encountered during shipping, in a retail nursery, or in a home landscape setting (Cameron et al., 2008; Guo et al., 2018).

The production of more compact plants could also influence shipping costs (Burnett and van Iersel, 2008). Container plants are often stacked or racked during shipping (Eaton and Appleton, 2014), meaning smaller, more compact plants create the potential to fit more plants on a truck. It is beneficial to both producers and consumers if more plants can fit onto a truck because it helps distribute shipping costs onto more plants.

Sensor-controlled irrigation studies have shown the relationship between plant growth and substrate volumetric water content (VWC) threshold for many ornamental plants, including 'Panama Red' hibiscus (Hibiscus acetosella), gardenia (Gardenia jasminoides), lantana (Lantana camara) 'Siskiyou Pink' gaura (Gaura lindheimeri), 'Mini Penny' hydrangea (Hydrangea macrophylla), rosemary (Rosmarinus officinalis), canadian columbine (Aquilegia canadensis), and 'Bath's Pink' cheddar pinks (Dianthus gratianopolitanus) (Bayer et al., 2013, 2014, 2015; Burnett and van Iersel, 2008; van Iersel et al., 2009; Zhen et al., 2014). The timing of deficit irrigation applications has been reported to affect flower bud development along with controlling plant growth. Flowering has been either promoted or inhibited depending on the species and degree of water stress (Álvarez et al., 2009, 2013; Cameron et al., 1999; Koniarski and Matysiak, 2013; Sharp et al., 2009). More information is needed on the timing of deficit irrigation applications on the growth and flowering of ornamental species to best use this method. The objective of this study was to determine the effectiveness of RI timing on growth, flowering, and quality of the popular herbaceous perennials coneflower and sneezeweed.

\section{Materials and methods}

Research was conducted in a glass greenhouse at the University of Massachusetts in Amherst, MA, from 5 Apr. 2017 to 1 Aug. 2017 as two separate experiments. Irrigation treatments and data collection were the same in both experiments. Greenhouse air temperature setpoints were $70{ }^{\circ} \mathrm{F}$ during the day and $65^{\circ} \mathrm{F}$ at night during the experimental period. The greenhouse was set for a 16-h daylength.

\section{Plant material}

EXPT. 1. Rooted cuttings of coneflower were obtained from Pioneer Gardens Inc. (Deerfield, MA) and potted up on 5 Apr. 2017. Cuttings were planted in 3 -qt black plastic containers filled with a commercial substrate containing bark, peat, dolomitic limestone, a wetting agent, and starter nutrients (Fafard RSI Nursery Mix; Sun Gro Horticulture, Agawam, MA). Containers were topdressed with $11 \mathrm{~g}$ of $18 \mathrm{~N}-$ 2.6P-6.6K controlled-release fertilizer (Nutricote Total 18-6-8, 180 d; Chisso-Ashai Fertilizer Co., Tokyo, Japan). Plants were hand-watered for 3 weeks to allow root establishment before irrigation treatments were initiated on 26 Apr. 2017. Treatment setpoints were switched on 11 May 2017, and the experiment was concluded on 8 June 2017. Plants experienced varying degrees of iron deficiency due to the $\mathrm{pH}$ of irrigation water and were treated one time with a foliar application of iron $(\mathrm{Fe})$ chelate [Sequestrene $330 \mathrm{Fe}(10 \% \mathrm{Fe})$; BASF Corp., Ludwigshafen, Germany] at a rate of 1 teaspoon/gal.

Expт. 2. Rooted cuttings of sneezeweed were obtained from Pioneer Gardens Inc. and planted on 26 May 2017. Cuttings were planted in 3-qt black plastic containers filled with a commercial substrate (Fafard RSI Nursery Mix). Containers were topdressed with $15 \mathrm{~g}$ of $18 \mathrm{~N}-2.18 \mathrm{P}-$ $6.6 \mathrm{~K}$ controlled release fertilizer (Osmocote Blend 18-5-8, 3-4 month; ICL Specialty Fertilizers, Dublin, $\mathrm{OH})$. The fertilizer was changed from the previous species to account for the $\mathrm{pH}$ issue with the irrigation water discovered during the coneflower experiment. Plants were hand-watered for 3 weeks to allow root establishment before irrigation treatments were initiated on 16 June 2017. Treatment setpoints were switched on 30 June 2017 . The experiment was concluded on 1 Aug. 2017.

\section{Treatments and data collection}

There were four substrate water content treatments for the coneflower experiment: a well-watered (WW) control $(38 \%)$, an RI control $(25 \%)$, altering water content from WW to RI ( $38 \%$ to $25 \%$; WWRI) after 2 weeks and altering water content from RI to WW (25\% to 38\%; RIWW) after 2 weeks (Fig. 1). Treatments were the same for the sneezeweed

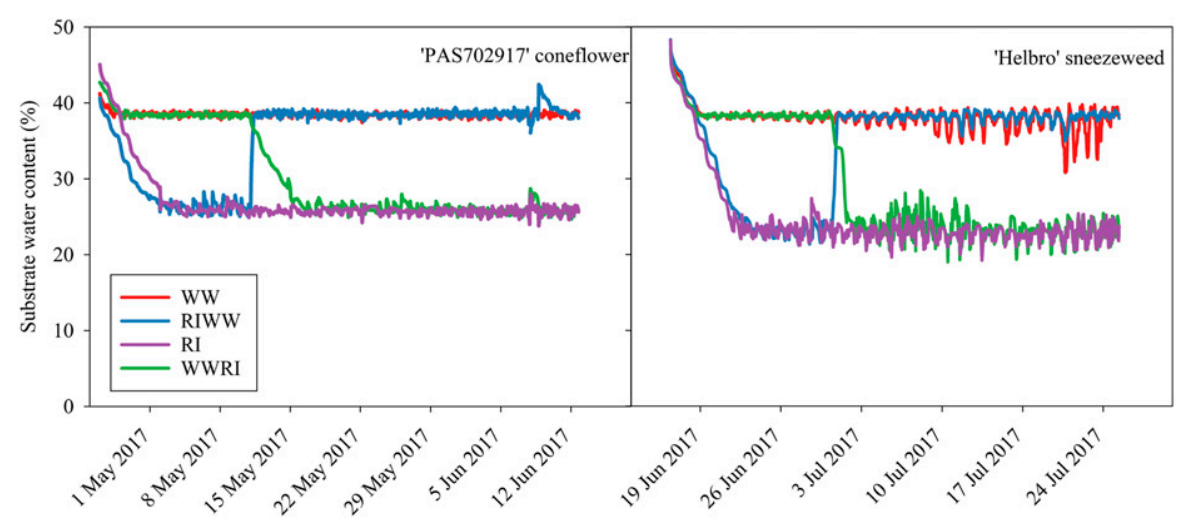

Fig. 1. Substrate water content treatments over the course of the 44- and 47d experiments. Well-watered and reduced irrigation controls for coneflower were maintained at volumetric water contents of $38 \%$ and $25 \%$, respectively. Well-wateredreduced irrigation and reduced irrigation-well-watered treatments had the volumetric water content setpoint changed after 2 weeks. Irrigation treatments were the same for sneezeweed except that the reduced irrigation was lowered to $20 \%$. 
Table 1. Growth measurements for coneflower and sneezeweed in response to irrigation treatments at the conclusion of the 44- and 47-d experiments. Compactness was calculated as shoot dry weight/shoot length. Well-watered (WW) and reduced irrigation (RI) controls for coneflower were maintained at volumetric water contents of $38 \%$ and $25 \%$, respectively. Well-watered - reduced irrigation (WWRI) and reduced irrigation - well-watered (RIWW) treatments had the volumetric water content setpoint changed after 2 weeks. Irrigation treatments were the same for sneezeweed except the reduced irrigation was lowered to $20 \%$.

\begin{tabular}{lccccc}
\hline Treatment & $\begin{array}{c}\text { Peduncle } \\
\text { length }(\mathbf{c m})^{\mathbf{z}}\end{array}$ & $\begin{array}{c}\text { Shoot dry } \\
\mathbf{w t}(\mathbf{g})^{\mathbf{z}}\end{array}$ & $\begin{array}{c}\text { Compactness } \\
\left(\mathbf{g} \cdot \mathbf{m}^{-\mathbf{l}}\right)^{\mathbf{z}}\end{array}$ & $\begin{array}{c}\text { Leaf area } \\
\left(\mathbf{c m}^{\mathbf{2}}\right)^{\mathbf{z}}\end{array}$ & $\begin{array}{c}\text { Flowers } \\
(\mathbf{n o} .)\end{array}$ \\
\hline Coneflower & & & & & \\
WW & $36.8 \mathrm{a}^{\mathrm{y}}$ & $14.1 \mathrm{a}$ & $0.039 \mathrm{a}$ & $1487.6 \mathrm{a}$ & $9.33 \mathrm{a}$ \\
RWWW & $35.7 \mathrm{a}$ & $14.4 \mathrm{a}$ & $0.039 \mathrm{a}$ & $1101.5 \mathrm{a}$ & $8.07 \mathrm{a}$ \\
WWRI & $26.6 \mathrm{~b}$ & $11.1 \mathrm{a}$ & $0.035 \mathrm{a}$ & $939.7 \mathrm{a}$ & $8.88 \mathrm{a}$ \\
RI & $27.0 \mathrm{~b}$ & $12.8 \mathrm{a}$ & $0.046 \mathrm{a}$ & $1122.4 \mathrm{a}$ & $8.0 \mathrm{a}$ \\
$P$ & 0.006 & 0.53 & 0.13 & 0.11 & 0.34 \\
Sneezeweed & & & & & \\
WW & $57.2 \mathrm{a}$ & $49.8 \mathrm{a}$ & $0.087 \mathrm{a}$ & $4395.1 \mathrm{a}$ & $99.3 \mathrm{a}$ \\
RIWW & $48.3 \mathrm{c}$ & $32.7 \mathrm{~b}$ & $0.066 \mathrm{ab}$ & $2955.0 \mathrm{a}$ & $77.1 \mathrm{ab}$ \\
WWRI & $51.2 \mathrm{~b}$ & $32.0 \mathrm{~b}$ & $0.062 \mathrm{~b}$ & $2479.3 \mathrm{a}$ & $63.3 \mathrm{~b}$ \\
RI & $51.3 \mathrm{~b}$ & $30.7 \mathrm{~b}$ & $0.06 \mathrm{~b}$ & $2334.6 \mathrm{a}$ & $67.9 \mathrm{~b}$ \\
$P$ & 0.002 & 0.001 & 0.05 & 0.06 & 0.02 \\
\hline
\end{tabular}

${ }^{\mathrm{z}} 1 \mathrm{~cm}=0.3937$ inch, $1 \mathrm{~g}=0.0353 \mathrm{oz}, 1 \mathrm{~g} \cdot \mathrm{m}^{-1}=0.0108 \mathrm{oz} / \mathrm{ft}, 1 \mathrm{~cm}^{2}=0.1550$ inch $^{2}$.

${ }^{\mathrm{y}}$ Means within a column with different letters are different $(\alpha=0.05)$ according to the Tukey's honestly significant difference tests. Each value is the mean of three replications with each replication consisting of five pseudoreplicate plants.

experiment except that the RI was changed to $20 \%$ to provide greater water stress.

A soil moisture sensor-controlled irrigation system, based on that described by Nemali and van Iersel (2006) was used for irrigation. Soil moisture sensors (10HS; Decagon Devices, Pullman, WA) were inserted into two pots in each of the 12 lines at a $45^{\circ}$ angle into the center of the substrate so that the entire sensor was in the substrate. The 24 sensors were connected to a multiplexer (AM16/32B; Campbell Scientific, Logan, UT) connected to a datalogger (CR1000; Campbell Scientific).

The datalogger measured sensor voltage output every $60 \mathrm{~min}$. The voltage readings from the sensors were converted to VWC using a substrate specific calibration [VWC = $-0.4207+0.0009 \times$ output $(\mathrm{V})]$ using the method described by Nemali et al. (2007). When both sensors in a line were below the line VWC threshold $(20 \%$ or $38 \%)$, the datalogger signaled the relay driver (SDMI6AC/ DC controller; Campbell Scientific) to open the appropriate solenoid valve (Rainbird, Azusa, CA). Plants were irrigated for $1 \mathrm{~min}$, applying 35 $\mathrm{mL}$ of water via drip tubbing connected to pressure-compensated drip emitters (Netafim USA, Fresno, CA). Readings from each sensor were averaged and recorded every $60 \mathrm{~min}$ and number of irrigation events per line was recorded daily. Daily and total irrigation volume for a line was calculated from the number of irrigation events and the volume of water applied per irrigation events.

Height (from the substrate to the tallest growing point), width (the widest diameter and $90^{\circ}$ from the widest diameter), and number of flowers were measured biweekly. For the majority of the experiment plant height was the peduncle length. Leaf area was measured using a leaf area meter (LI-3100C; LI-COR, Lincoln, $\mathrm{NE}$ ). Shoots were cut off at the substrate surface and dried at $50{ }^{\circ} \mathrm{C}$ for 1 week, after which dry weight was determined. Compactness was calculated as shoot dry weight/plant height. Growth index (GI) was calculated as follows: (height + width $1+$ width 2 ) $\div 3$ (Warsaw et al., 2009) Relative chlorophyll content was measured using a chlorophyll meter (SPAD 502DL Plus; Konica Minolta, Osaka, Japan). Stomatal conductance $\left(g_{s}\right)$ was measured using a leaf porometer (SC-1; Decagon Devices). Water use efficiency (WUE) was calculated as grams shoot dry weight/ irrigation volume (Flax et al., 2018).

\section{Experimental design and data analysis}

The experiment was designed as a randomized complete block with four treatments (substrate VWC set points) and three replications for a total of 12 plots with five pseudoreplicate plants each. Data were analyzed using the PROC GLM procedure of SAS (version 9.4; SAS Institute, Cary, NC) with $P=0.05$ considered statistically significant. Treatment means were separated using Tukey's honestly significant difference.

\section{Results and discussion}

Coneflower peduncle length was greater for the plants receiving the WW $[($ mean $\pm \mathrm{sD}) 36.8 \pm 2.6 \mathrm{~cm}]$ and RIWW $(35.7 \pm 3.8 \mathrm{~cm})$ irrigation treatments than for plants receiving the RI $(27.0 \pm 2.2 \mathrm{~cm})$ and WWRI $(26.6 \pm 5.3 \mathrm{~cm})$ treatments (Table 1$)$. Sneezeweed peduncle length was greatest for plants receiving the WW irrigation treatment $(57.2 \pm 1.7 \mathrm{~cm})$ and least for plants receiving the RIWW $(48.3 \pm 4.7 \mathrm{~cm})$ treatment. There was no difference in shoot dry weight for coneflower. Sneezeweed shoot dry weight was greatest for plants receiving the WW treatment with shoot dry weight reduced by $34 \%, 36 \%$, and $38 \%$ for the RIWW, WWRI, and RI treatments, respectively. Sneezeweed was more compact for the WWRI and $\mathrm{RI}$ treatments than the WW treatment, which was not different from the RIWW treatment. Compactness was not significant for coneflower.

Plant height (peduncle length) responses are similar to other reports, which reported that plant height decreased with drought severity or lower VWC. Height and shoot dry weight of carnation (Dianthus caryophyllus), cheddar pinks, and rosemary all decreased with increasing level of water stress (Álvarez et al., 2009; Zhen et al., 2014). Niu et al. (2007) found that shoot dry weight of big bend bluebonnet (Lupinus havardii) generally increased with VWC, but there was not a significant difference for the $20 \%, 25 \%$, and $33 \%$ setpoints. Conversely, 'New Gold' lantana and cardinal flower (Lobelia cardinalis) height and shoot dry weight did not differ for plants irrigated to container capacity, exposed to two drought cycles, or exposed to one of two timings of drought cycle (Starman and Lombardini, 2006). 'Henry 


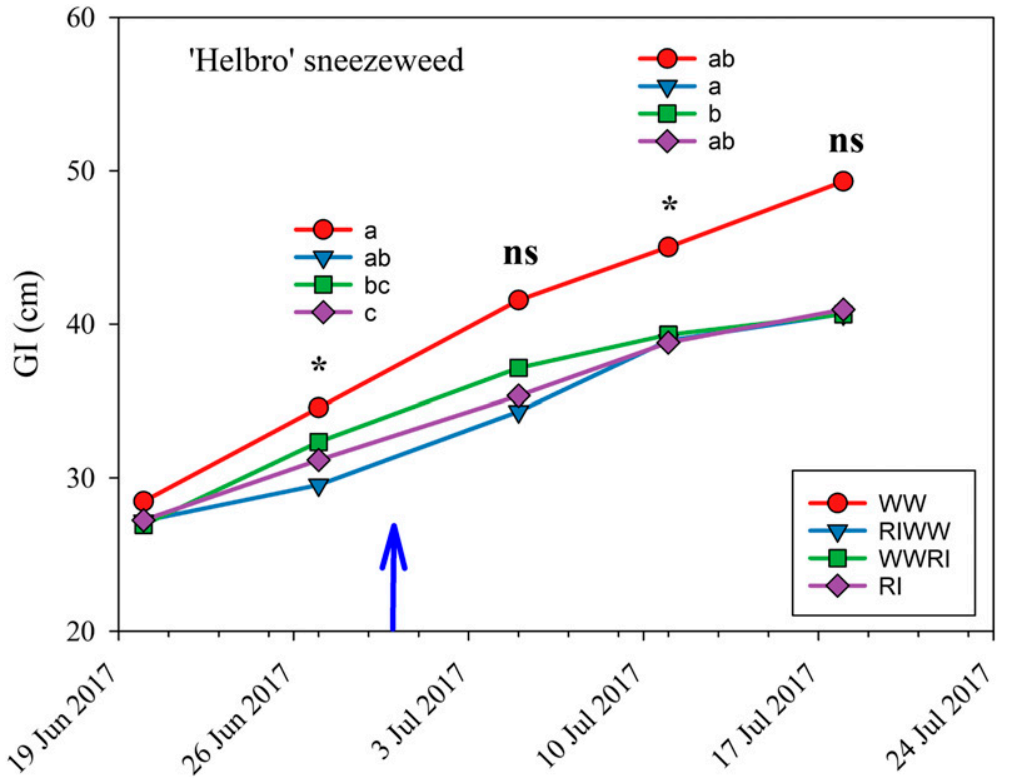

Fig. 2. Growth index (GI) of sneezeweed receiving one of four irrigation treatments. Well-watered (WW) and reduced irrigation (RI) controls maintained volumetric water contents of $38 \%$ and $20 \%$, respectively. Well-watered - reduced irrigation (WWRI) and reduced irrigation - well-watered (RIWW) treatments had the volumetric water content setpoint being maintained changed after 2 weeks (indicated by the arrow). GI was calculated as follows: (height + width $1+$ width 2$) \div 3$. Means followed by the same letters are not different according to the Tukey's honestly significant difference tests, $n s=$ not significant $(n=3)$; $1 \mathrm{~cm}=0.3937$ inch.

Duelberg' mealycup sage (Salvia farinacea) and 'New Wonder' fan-flower (Scaevola aemula) exposed to the same irrigation treatments showed a species-specific response.

The timing and duration of water stress could also contribute to plant growth responses. Koniarski and Matysiak (2013) found that height of rhododendron (Rhododendron) cultivars Old Port and Catabiense Boursault was reduced by $21 \%$ and $16 \%$, respectively, when deficit irrigation was applied during the vegetative growth phase. Whereas height was only reduced by $8 \%$ to $13 \%$ for 'Old Port' and was not significantly reduced for 'Catabiense Boursault' when deficit irrigation was applied during the flowering phase. Alvarez et al. (2013) found geranium (Pelargonium $\times$ hortorum) height was least when deficit irrigation was applied during the flowering phase, and there was no difference in plant height if regulated deficit irrigation was applied during the vegetative phase. Geranium shoot dry weight decreased with exposure to deficit irrigation regardless of the timing of the deficit irrigation (vegetative or flowering development phase). Results of this study are similar to the those of Starman and Lombardini (2006) in that there was a species-specific response to irrigation treatments that likely resulted in differences in species response to water stress and greater RI experiences by sneezeweed.

There was no difference among the treatments in total leaf area for coneflower or sneezeweed (Table 1). Coneflower GI was unaffected by irrigation treatment throughout the experiment (data not shown). Sneezeweed GI was significant at the second and fourth measurement dates (Fig. 2). At the second measurement date, the WW and WWRI treatments were greater than the RI and RIWW treatments. This reflects that the WW and WWRI were both receiving the WW treatment and the RI and RIWW were both receiving the RI treatment at that time. At the fourth measurement date, GI of the RIWW was greater than the WWRI treatment indicating that the switch in substrate water contents that occurred for those treatments increased and decreased the growth rate, respectively.

Plants vary in both morphological and physiological responses to reduced substrate water content (Kramer and Boyer, 1995). Variability in responses can be attributed to both physiological and morphological adaptations, as well as the ability to acclimate to water stress. Leaf area can be an indicator for drought stress because leaf cell elongation is sensitive to low water potentials (Lambers et al., 2008). Reduced cell elongation due to water stress could also contribute to reduced stem elongation (Taiz and Zeiger, 2010). In this study, RI did not result in a reduction in leaf area for either species; however, differences in peduncle length for both species indicate that cell elongation was affected by treatments. Species differences in response to the changing irrigation treatment may reflect a difference in adaptations and acclimation. For example, coneflower is native to the prairies of the central and southeastern United States and is adaptable to drought (Armitage, 2008). Sneezeweed is intolerant of dry soils and performs best in medium to wet soil. These differences could explain lack of treatment response by coneflower and the greater growth of sneezeweed with the WW treatment.

Number of flowers for sneezeweed was greater for the WW treatment $[($ mean $\pm \mathrm{SD}) 99 \pm 6$ flowers $]$ than the WWRI and RI treatments $(63 \pm 4$ and $68 \pm 2$ flowers, respectively), which were similar to the RIWW treatment $[77 \pm 7$ flowers, $P=0.02$ (Table 1 )]. There was no significant difference in number of flowers for coneflower.

Flowering is sensitive to timing of water stress. Rose (Rosa $\times$ bybrida) flower development was most sensitive to drought before petal and stamen initiation (Chimonidou-Pavlidou, 2004). Flowering of geranium was lowest when deficit irrigation was applied during the flowering stage (Alvarez et al., 2013). Conversely, Koniarski and Matysiak (2013) found that 'Catawiense Boursault' rhododendron had a higher number of inflorescence buds when deficit irrigation was applied during the flowering stage and that deficit irrigation do not negatively affect number of inflorescence buds of rhododendron cultivars.

Similar to coneflower in this study, there was no difference in flower number for lantana, cardinal 
Table 2. Leaf greenness (SPAD), stomatal conductance ( $\left.g_{s}\right)$, and total irrigation volumes for coneflower and sneezeweed in response to different irrigation treatments at the conclusion of the 44- and 47-d experiments. Well-watered (WW) and reduced irrigation (RI) controls for coneflower were maintained at volumetric water contents of $38 \%$ and $25 \%$, respectively. Well-watered - reduced irrigation (WWRI) and reduced irrigation - well-watered (RIWW) treatments had the volumetric water content setpoint changed after 2 weeks. Irrigation treatments were the same for sneezeweed except the reduced irrigation was lowered to $20 \%$.

\begin{tabular}{|c|c|c|c|c|}
\hline & SPAD & $\mathscr{g s}_{\mathrm{s}}\left(\mathrm{mmol} \cdot \mathrm{m}^{-2} \cdot \mathrm{s}^{-1}\right)$ & Total irrigation vol $(\mathrm{L} / \text { plant })^{\mathrm{z}}$ & Water-use efficiency $\left(\mathrm{g} \cdot \mathrm{L}^{-1}\right)^{\mathrm{z}}$ \\
\hline \multicolumn{5}{|c|}{ Coneflower } \\
\hline WW & $38.6 \mathrm{a}^{\mathrm{y}}$ & $397.3 \mathrm{a}$ & $5.2 \mathrm{a}$ & $2.8 \mathrm{a}$ \\
\hline WWRI & $40.6 \mathrm{a}$ & $368.3 \mathrm{a}$ & $3.5 \mathrm{c}$ & $3.2 \mathrm{a}$ \\
\hline RI & $41.9 \mathrm{a}$ & $443.5 \mathrm{a}$ & $3.7 \mathrm{bc}$ & $3.5 \mathrm{a}$ \\
\hline$P$ & 0.34 & 0.06 & 0.02 & 0.11 \\
\hline RIWW & $55.9 \mathrm{ab}$ & $208.1 \mathrm{a}$ & $8.8 \mathrm{~b}$ & $3.7 \mathrm{~b}$ \\
\hline WWRI & $57.2 \mathrm{a}$ & $182.6 \mathrm{ab}$ & $7.4 \mathrm{~b}$ & $4.3 \mathrm{a}$ \\
\hline RI & $58.1 \mathrm{a}$ & $145.8 \mathrm{~b}$ & $6.7 \mathrm{~b}$ & $4.6 \mathrm{a}$ \\
\hline$P$ & 0.005 & 0.05 & 0.004 & $<0.001$ \\
\hline
\end{tabular}

${ }^{\mathrm{z}} \mathrm{l} \mathrm{L}=0.2642 \mathrm{gal}, \mathrm{l} \mathrm{g} \cdot \mathrm{L}^{-1}=0.1335 \mathrm{oz} / \mathrm{gal}$.

${ }^{y}$ Means within a column with different letters are different $(\alpha=0.05)$ according to the Tukey's honestly significant difference tests. Each value is the mean of three replications with each replication consisting of five pseudoreplicate plants.

flower, mealycup sage, or fan-flower whether irrigated to container capacity or exposed to one or two drought cycles (Starman and Lombardini, 2006). Álvarez et al. (2009) found that number of flowers per plant for carnation was not different for plant receiving moderate deficit irrigation or the control. Other studies were similar to the results for sneezeweed. Number of racemes of big bend bluebonnet was reduced for the $12 \%$ and $15 \%$ VWC treatments by $35 \%$ compared with the $20 \%$ to $33 \%$ treatments (Niu et al., 2007). Alem et al. (2015) found bract size of 'Classic Red' poinsettia (Euphorbia pulcherrima) was reduced by $53 \%, 47 \%$, and $31 \%$ for the water deficit treatments. Number of flowers of 'RADrazz' rose and 'Belinda's Dream' were not different for plants maintained at 30\% and $40 \%$ VWC; however, flower number was reduced by $27 \%$ and $86 \%$ for the $20 \%$ and $10 \%$ treatments for 'RADrazz' rose and by $42 \%$ and $75 \%$ for the $20 \%$ and $10 \%$ treatments for 'Belinda's Dream' rose (Cai et al., 2014). Species variability, similar to plant growth, indicates species-specific response based on adaptation features, severity of water stress, or ability to acclimate to drought. The degree of RI for coneflower, a drought-adapted species, was not great enough to effect flower development, whereas the degree of RI for sneezeweed, a species intolerant of drought conditions, resulted in differences in flower development, as represented by flower number.

Leaf greenness of sneezeweed, as determined by leaf SPAD readings, for plants receiving the WWRI and RI treatments were greater than WW treatment, which was similar to RIWW treatment (Table 2). Stomatal conductance of sneezeweed was similar between treatments except RI was lower than RIWW $P=0.05$ (Table 2)]. Leaf greenness and $g_{s}$ were unaffected by irrigation treatment for coneflower.

Increased leaf greenness with RI could be the result of lower leaf water content, increased leaf thickness, or increased leaf chlorophyll content (Martínez and Guiamet, 2004). Similar to this study, heliotrope (Heliotropium arborescens) and angeolonia (Angelonia angustifolia) had higher SPAD reading for plants maintained at $20 \%$ VWC than plants maintained at $40 \%$ VWC (Guo et al., 2018). SPAD readings of big bend bluebonnet was less for plants receiving the $15 \%$ and $20 \%$ VWC treatments than for higher VWC treatments (Niu et al., 2007). However, it was concluded that these plants may have reached senescence due to water stress, which would explain reduced greenness.

A reduction in $g_{S}$ is commonly observed in water-stressed plants (Nemali and van Iersel, 2008). This further indicates that the reduced irrigation treatment did not result in water stress for coneflower, which is adapted to drought. Conversely, water-sensitive sneezeweed had reduced conductance for the RI treatment, indicating water stress. Stomatal conductance decreased linearly with decreasing VWC for canadian columbine. It also decreased with decreasing VWC for cheddar pinks, although the trend was not significant (Zhen et al., 2014). Cai et al. (2014) reported no difference in $g_{S}$ for 'RADrazz' or 'Belinda's Dream' roses at $30 \%$ and $40 \%$ VWC. For both cultivars, gs was lowest at $10 \%$ VWC.

Irrigation volume was highest for the WW treatment for both species (Table 2). For sneezeweed WW irrigation volume was greater than all other irrigation treatments $(P<0.001)$. Over the course of the experiment, the WW plants received $15.1 \mathrm{~L} /$ plant of water, while the RIWW, WWRI, and RI treatments received $42 \%, 51 \%$, and $56 \%$ less water, respectively. For coneflower WW irrigation volume was greater than RI and WWRI, which was the least. The WW treatment received $\mathbf{5 . 2}$ $\mathrm{L} /$ plant of water, while the RIWW, RI, and WWRI treatments received $11 \%, 29 \%$, and $33 \%$ less water, respectively. Water use efficiency of sneezeweed was greater for the RI and WWRI treatments (4.6 and 4.3 $\mathrm{g} \cdot \mathrm{L}^{-1}$, respectively) than the RIWW and WW treatments [3.7 and 3.3 $\mathrm{g} \cdot \mathrm{L}^{-1}$, respectively $\left.(P<0.001)\right]$. Water use efficiency was not significant 

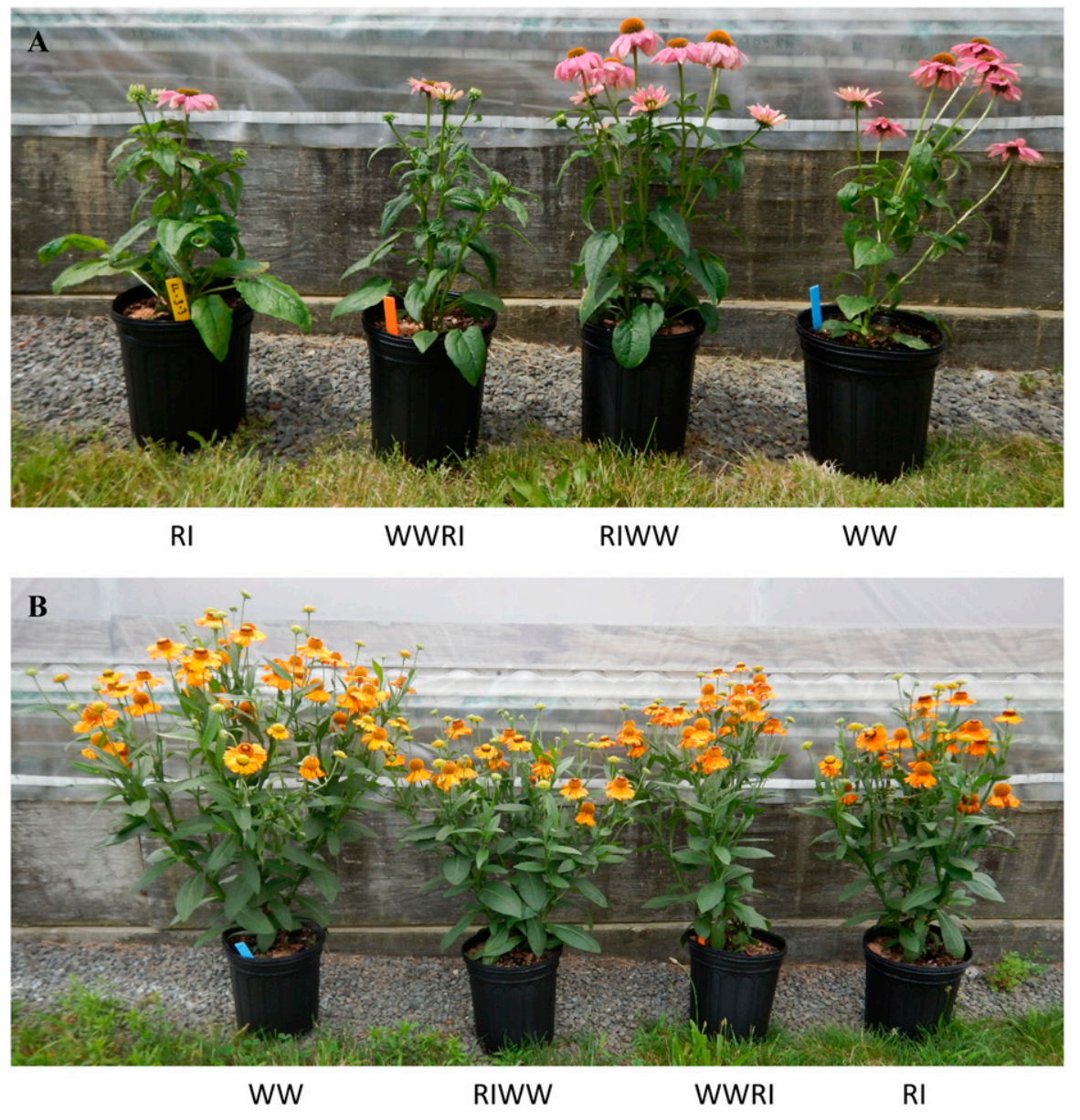

Fig. 3. Photographs of coneflower (A) and sneezeweed (B) at the conclusion of the 44- and 47-d experiments. Well-watered (WW) and reduced irrigation (RI) controls for coneflower were maintained at volumetric water contents of $38 \%$ and $\mathbf{2 5 \%}$, respectively. Well-watered - reduced irrigation (WWRI) and reduced irrigation - well-watered treatments (RIWW) had the volumetric water content setpoint changed after 2 weeks. Irrigation treatments were the same for sneezeweed except the reduced irrigation was lowered to $20 \%$.

for coneflower. Differences in total irrigation volume between species reflects species water requirements; environmental variability during the two experiments would also affect plant water requirements.

For sneezeweed, irrigation volume was substantially reduced for all treatments that included RI at some time during the experiment. The WW plants exhibited signs of exuberant growth that would be undesirable in a retail setting (Fig. 2). Plants in the other treatments had overall better appearance. Water use efficiency was greater for plants that received RI during the second part of the experiment. Increased water use efficiency along with a moderate reduction in peduncle length indicate that RI can be used for growth control and water savings for sneezeweed. For coneflower, irrigation volume was also
Sneezeweed receiving the WW treatment were very large and not as visually appealing as plants in other treatments (Fig. 3). These plants would be more likely to be damaged during shipping or in a retail setting. Plants receiving the other treatments appeared more uniform. From the results of this study, using RI to alter growth is more effective for species that are not drought tolerant, such as sneezeweed. Droughttolerant species, such as coneflower, are adapted to water stress and are not as affected by RI. It is possible that a lower substrate water content could affect growth of coneflower and be used for growth control. The results of this study indicate that RI for growth control requires species-specific knowledge of how plant growth is affected by RI and the degree of RI needed to produce a response. Further research is needed to understand if RI during production has long-term impacts on plant growth or improved water stress tolerance in a retail environment.

\section{Literature cited}

Alem, P., P.A. Thomas, and M.W. van Iersel. 2015. Use of controlled water deficit to regulate poinsettia stem elongation. HortScience 50:234-239.

Álvarez, S., A. Navarro, S. Bañon, and M.J. Sánchez-Blanco. 2009. Regulated deficit irrigation in potted Dianthus plants: Effects of severe and moderate water stress on growth and physiological responses. Scientia Hort. 122:579-585.

Álvarez, S., S. Bañon, and M.J. SánchezBlanco. 2013. Regulated deficit irrigation in different phenological stages of potted geranium plants: Water consumption, water relations, and ornamental quality. Acta Physiol. Plant. 35:1257-1267.

Armitage, A. 2008. Herbaceous perennial plants: A treatise on their identification, culture, and garden attributes. 3rd ed. Stipes Publ., Champaign, IL.

Bayer, A., I. Mahbub, M. Chappell, J. Ruter, and M.W. van Iersel. 2013. Water use and growth of Hibiscus acetosella 'Panama Red' grown with a soil moisture sensor-controlled irrigation system. HortScience 48:980-987.

Bayer, A., K. Whitaker, M. Chappell, J. Ruter, and M.W. van Iersel. 2014. Effect of irrigation duration and fertilizer rate on plant growth, substrate EC, and leaching volume. Acta Hort. 1034:477-484.

Bayer, A., J. Ruter, and M.W. van Iersel. 2015. Automated irrigation control for improved growth and quality of Gardenia 
jasminoides 'Radicans' and 'August Beauty'. HortScience 50:78-84.

Behe, B.K., B.L. Campbell, C.R. Hall, H. Khachatryan, J.H. Dennis, and C. Yue. 2013. Consumer preferences for local and sustainable plant production characteristics. HortScience 48:200-208.

Brand, M.H. and R.L. Leonard. 2001. Consumer product and service preference related to landscape retailing. HortScience 36:1111-1116.

Burnett, S.E. and M.W. van Iersel. 2008. Morphology and irrigation efficiency of Gaura lindheimeri grown with capacitance sensor-controlled irrigation. HortScience 43:1555-1560.

Cai, X., T. Starman, G. Niu, and C. Hall. 2014. The effect of substrate moisture content of growth and physiological responses of two landscape roses (Rosa bybrida L.). HortScience 49:741-745.

Cameron, R.W.F., R.S. Harrison-Murray, and M.A. Scott. 1999. The use of controlled water stress to manipulate growth of container-grown Rhododendron cv. Hoppy. J. Hort. Sci. Biotechnol. 74:161-169.

Cameron, R.W.F., R. Harrison-Murray, M. Fordham, S. Wilkinson, W. Davies, C. Atkinson, and M. Else. 2008. Regulated irrigation of woody ornamentals to improve plant quality and precondition against drought stress. Ann. Appl. Biol. 153:49-61.

Chappell, M., J. Owen, S. White, and J. Lea-Cox. 2013. Irrigation management practices. In: T. Yeager, T. Bilderback, D. Fare, C. Gilliam, J. Lea-Cox, A. Niemiera, J. Ruter, K. Tilt, S. Warren, T. Whitwell, and R. Write (eds.). Best management practices: Guide for producing nursery crops. 3rd ed. 17 Oct. 2019. <http:// contents.sna.org/bmpirrigation.html>.

Chimonidou-Pavlidou, D. 2004. Malformation of roses due to drought stress. Scientia Hort. 99:79-87.

Eaton, G.K. and B.L Appleton. 2014. Getting started in the nursery business: Nursery production options. Virginia Coop. Ext. Publ. 430-050.

Flax, N.J., C.J. Currey, A.G. Litvin, J.A. Schrader, D. Grewell, and W.R. Graves. 2018. Aesthetic quality and strength of bioplastic biocontainers at different substrate volumetric water contents. HortTechnology 53:483-490.

Fulcher, A., A.V. LeBude, J.S. Owen, Jr., S.A. White, and R.C. Beeson. 2016. The next ten years: Strategic vision of water resources for nursery producers. HortTechnology 26:121-132.
Glasgow, T.E., T.E. Bilderback, T. Johnson, K.E. Perry, and C.D. Safley. 1998. Evaluating consumer perceptions of plant quality. Proc. Southern Nursery Assn. Res. Conf. 43:497-500.

Guo, Y., T. Starman, and C. Hall. 2018. Reducing substrate moisture content (SMC) during greenhouse production and postproduction of Angelonia and Heliotrope improves crop quality and economic value. HortScience 53:1006-1011.

Hall, C.R., M.L. Jones, T. Starman, C. Pasian, and G. Staby. 2011. Shrink the shrink. 17 Oct. 2019. <https://www. greenhousemag.com/article/greenhouse0111 -shrink/>.

Kaufmann, P.H., R.J. Joly, and P.A. Hammer. 2000. Influence of day and night temperature differentials on root elongation rate, root hydraulic properties, and shoot water relations in chrysanthemum. J. Amer. Soc. Hort. Sci. 125:383-389.

Koniarski, M. and B. Matysiak. 2013. Growth and development of potted Rhododendron cultivars 'Catawbiense Boursault' and 'Old Port' in response to regulated deficit irrigation. J. Hort. Res. 21:29-37.

Kramer, P.J. and J.S. Boyer. 1995. Water relations of plants and soils. Academic Press, San Diego, CA.

Lambers, H., T.L. Pons, and S. Chapin. 2008. Plant physiological ecology. 2nd ed. Springer Verlag, New York, NY.

Lichtenberg, E., J. Majsztrik, and M. Saavoss. 2013. Profitability of sensorbased irrigation in greenhouse and nursery crops. HortTechnology 23:770-774.

Martínez, D. and J. Guiamet. 2004. Distortion of the SPAD 502 chlorophyll meter readings by changes in irradiance and leaf water status. Agronomie 24:41-46.

Million, J., T. Yeager, and J. Albano. 2007. Consequences of excessive overhead irrigation on runoff during container production of sweet viburnum. J. Environ. Hort. 25:117-125.

Nemali, K.S. and M.W. van Iersel. 2006. An automated system for controlling drought stress and irrigation in potted plants. Scientia Hort. 110:292-297.

Nemali, K.S., F. Montesano, S.K. Dove, and M.W. van Iersel. 2007. Calibration and performance of moisture sensors in soilless substrates: $\mathrm{ECH}_{2} \mathrm{O}$ and Theta probes. Scientia Hort. 112:227-234.
Nemali, K.S. and M.W. van Iersel. 2008. Physiological responses to different substrate water contents: Screening for high water-use efficiency in bedding plants. J. Amer. Soc. Hort. Sci. 133:333-340.

Niu, G., D.S. Rodriguez, L. Rodriguez, and W. Mackay. 2007. Effect of water stress on growth and flower yield of big bend bluebonnet. HortTechnology 17:557-560.

Owen, J.S., S.L. Warren, T.E. Bilderback, and J.P. Albano. 2008. Phosphorus rate, leaching fraction, and substrate influence on influent quantity, effluent nutrient content, and response of a containerized woody ornamental crop. HortScience 24:906-912.

Sánchez-Blanco, M.J., S. Álvarez, A. Navarro, and S. Bañon. 2002. Comparative growth and water relation of Cistus albidus and Cistus monspeliensis plants during water deficit conditions and recovery. Plant Sci. 162:107-113.

Sharp, R.G., M.A. Else, R.W. Cameron, and W.J. Davies. 2009. Water deficits promote flowering in Rhododendron via regulation of pre and post initiation development. Scientia Hort. 120:511-517.

Starman, T. and L. Lombardini. 2006. Growth, gas exchange, and chlorophyll fluorescence of four ornamental herbaceous perennials during water deficit conditions. J. Amer. Soc. Hort. Sci. 131:469-475.

Taiz, L. and E. Zeiger. 2010. Plant physiology. 5th ed. Sinauer Assoc., Sunderland, MA.

van Iersel, M.W., R.M. Seymour, M. Chappell, F. Watson, and S. Dove. 2009. Soil moisture sensor-based irrigation reduced water use and nutrient leaching in a commercial nursery. Proc. Southern Nursery Assn. 54:17-21.

Warsaw, A.L., R.T. Fernandez, B.M. Cregg, and J.A. Andresen. 2009. Container-grown ornamental plant growth and water runoff nutrient content and volume under four irrigation treatments. HortScience 44:1573-1580.

Zhen, S., S.E. Burnett, M.E. Day, and M.W. van Iersel. 2014. Effects of substrate water content on morphology and physiology of rosemary, canadian columbine, and cheddar pink. HortScience 49:486-492. 